\title{
KARAKTERISTIK IBU HAMIL BERHUBUNGAN DENGAN PENGETAHUAN DALAM PENGGUNAAN KONTRASEPSI PASCA PERSALINAN
}

\author{
Rita Kartika Sari ${ }^{1 凶}$, Yulice Soraya Nur Intan ${ }^{1}$, Livana $\mathbf{P H}^{2}$ \\ ${ }^{1}$ Fakultas Kedokteran Universitas Islam Sultan Agung Semarang \\ ${ }^{2}$ Progran Studi Sarjana Keperawatan dan Profesi Ners Sekolah Tinggi Ilmu Kesehatan Kendal
}

\section{ARTICLE INFO \\ Article history \\ Submitted : 2020-04-12 \\ Revised : 2020-10-19 \\ Accepted : 2020-12-29}

\section{Keywords:}

Characteristics

Pregnant women

Knowledge

Contraception

Postpartum

\section{Kata Kunci:}

Karakteristik

Ibu hamil

Pengetahuan

Kontrasepsi

Pasca persalinan

\section{$\triangle$ Corresponding Author:}

\begin{abstract}
Pregnancy is a maturation crisis that can be stressful. The maturation crisis can be overcome if the mother is ready to enter a new phase where she is ready to take on the responsibilities of being a parent and a new role so that the mother must take care of her health to prevent complications of pregnancy. Pregnancy complications can be prevented by maintaining the distance of pregnancy between one child with another child through postpartum contraception. The study aimed to determine the characteristics of pregnant women who have sufficient and good knowledge of the use of postpartum contraception. Quantitative research with an exploratory descriptive approach has been carried out on 34 pregnant women who performed antenatal care at the Kedung 2 Jepara Public Health Center. The data collection tool uses a questionnaire. Data were analyzed by univariate analysis using frequency distribution and bivariate analysis using test chi-square. The results showed that the average age of pregnant women was 29 years. The majority of pregnant women had the last high school education, work, and the average income was Rp. 1,500,000/month. The majority of pregnant women had one child and when data were collected for pregnant women who were 1st and 2nd pregnant status. The majority of pregnant women had a good level of knowledge about the use of postpartum injection contraception. The results of the chisquare test analysis showed that the characteristics of pregnant women that had a significant relationship with knowledge about the use of postpartum contraception were age $(p=0.027)$, education $(p=0.004)$, occupation $(p=0.002)$, number of children $(p=$ $0.006)$. Meanwhile, income did not have a significant relation with maternal knowledge in using postpartum contraception $(\mathrm{p}=0.923)$.

Kehamilan merupakan krisis maturasi yang dapat menimbulkan stres. Krisis maturasi tersebut dapat diatasi jika ibu siap akan memasuki fase baru yaitu siap mengemban tanggung jawab sebagai orang tua dan peran baru, sehingga ibu harus menjaga kesehatan agar tidak terjadi komplikasi kehamilan. Komplikasi kehamilan dapat dicegah salah satunya dengan menjaga jarak kehamilan antara anak yang satu dengan anak yang lainnya melalui kontrasepsi pasca persalinan. Penelitian bertujuan untuk mengetahui hubungan karakteristik ibu hamil dengan pengetahuan dalam penggunaan kontrasepsi pasca persalinan. Penelitian kuantitatif dengan pendekatan deskriptif eksploratif telah dilaksanakan pada ibu hamil yang melakukan pemeriksaan kehamilan di Puskesmas Kedung 2 Jepara yang berjumlah 34 orang. Alat pengumpul data menggunakan kuesioner. Data dianalisis secara univariat menggunakan distribusi frekuensi dan analisis bivariate menggunakan uji chi square. Hasil penelitian menunjukkan rerata usia ibu hamil 29 tahun. Mayoritas ibu hamil berpendidikan terakhir SLTA, bekerja, dan rerata penghasilan Rp. 1.500.000,-/bulan. Mayoritas ibu hamil telah memiliki anak berjumlah 1 dan saat pengambilan data ibu hamil berstatus hamil ke 1 dan ke 2. Mayoritas tingkat pengetahuan ibu hamil tentang penggunaan kontrasepsi suntik pasca persalinan berada pada tingkat pengetahuan baik. Hasil analisis uji chi square menunjukkan karakteristik ibu hamil yang mempunyai hubungan bermakna dengan pengetahuan dalam penggunaan kontrasepsi pasca persalinan yaitu usia $(\mathrm{p}=0,027)$, pendidikan $(\mathrm{p}=0,004)$, pekerjaan $(\mathrm{p}=0,002)$, jumlah anak $(\mathrm{p}=0,006)$. Sedangkan penghasilan tidak memiliki hubungan yang bermakna dengan pengetahuan ibu dalam penggunaan kontrasepsi pasca persalinan $(\mathrm{p}=0,923)$.
\end{abstract}

Rita Kartika Sari

Fakultas Kedokteran Universitas Islam Sultan Agung Semarang

Telp. 082225934333

Email: rita.kartika.sari@gmail.com 


\section{PENDAHULUAN}

Kehamilan merupakan situasi yang dinantikan bagi seorang wanita yang sudah menikah. Kehamilan dapat terjadi karena direncanakan ataupun tidak direncanakan. Kehamilan akan memberikan dampak pada individu tersebut ataupun anggota keluarga yang lain, yang mana mereka akan beradaptasi serta berinterpretasi yang berbeda-beda tergantung pada budaya dan tren sosial. Kehamilan membutuhkan waktu 9 bulan atau 40 minggu yang terbagi dalam 3 periode, yaitu trimester 1, trimester 2, dan trimester 3 (Susanti, 2008). Kehamilan merupakan krisis maturasi yang dapat menimbulkan stres. Krisis maturasi tersebut dapat diatasi jika ibu siap akan memasuki fase baru yaitu siap mengemban tanggung jawab sebagai orang tua dan peran baru, sehingga ibu harus menjaga kesehatan serta kehamilannya melalui pemeriksaan rutin. Pemeriksaan pada trimester pertama yang diberikan tenaga kesehatan rerata secara nasional $85 \%$, sedangkan di Jawa Tengah rerata $89,5 \%$. Adapun karakteristik ibu hamil tersebut mayoritas tidak bekerja, dan tinggal di perkotaan (Riskesdas, 2018).

Millenium Development Goal (MDGs) 2015 memiliki tujuan untuk meningkatkan kesehatan ibu dimana indikator utamanya penurunan angka kematian ibu menjadi 102 per 100.000 kelahiran hidup dan indikator proksinya adalah peningkatan persalinan yang ditolong oleh tenaga kesehatan menjadi 9\% pada tahun 2015. Keluarga berencana mempunyai kontribusi yang besar terhadap upaya penurunan angka kematian ibu melahirkan. Pengetahuan ibu tentang pengendalian KB merupakan salah satu aspek penting dalam pemahaman tentang berbagai macam alat kontrasepsi, selanjutnya hal ini akan sangat berpengaruh terhadap pemakaian alat kontrasepsi yang tepat dan efektif (Sari, 2018).

Namun tidak berbanding lurus dengan jumlah angka penggunaannya. Penggunaan alat kontrasepsi pada wanita usia $15-49$ tahun yaitu dari $61,4 \%$ (tahun 2007) menjadi $55,86 \%$ (tahun 2010). Pada ibu pasca salin hal ini sangat perlu mendapatkan perhatian dari dokter/perawat matenitas sehingga ibu dapat segera mendapat informasi yang benar dan memutuskan untuk memanfaatkan pelayanan KB di fasilitas kesehatan.
Menurut hasil penelitian, usia subur seorang wanita biasanya antara 15 - 49 tahun. Oleh karena itu untuk mengatur jumlah kelahiran atau menjarangkan kelahiran, wanita/ pasangan ini lebih diprioritas untuk menggunakan alat/cara KB (DKK Bali, 2012). Berdasarkan data dinas kesehatan provinsi Bali, pada tahun 2014 tercatat bahwa cakupan peserta KB aktif sebesar $83,87 \%$ dari seluruh pasangan usia subur yang tercatat, menurun dari tahun 2012 yaitu sebesar 84,4\%. Banyak hal yang menyebabkan pencapaian Pelayanan KB belum sesuai harapan. kegiatan Komunikasi, Informasi dan Edukasi (KIE) yang dilakukan kepada masyarakat belum mampu mengubah nilai tentang jumlah anak ideal yang diinginkan maupun perilaku masyarakat dalam mendapatkan pelayanan kontrasepsi sesuai kebutuhan (Buletin Kespro, 2013).

Pemeriksaan kehamilan di trimester pertama sangat penting untuk mengetahui kondisi janin di dalam rahim serta memantau tumbuh kembang janin dengan baik. Adapun pemeriksaan yang dapat dilakukan adalah cek darah, urin, dan pemeriksaan USG. Cek darah dilakukan untuk imunitas terhadap penyakit Rubella dan cacar air, kemungkinan penyakit Hepatitis B, Sifilis, HIV, memantau tingkat hemoglobin dalam darah, jenis golongan darah dan rhesusnya, serta untuk mengetahui kemungkinan terpaparnya atau tidak penyakit toxoplasmosis. Pemeriksaan urin dilakukan untuk mengetahui ada atau tidaknya infeksi saluran kemih ataupun ginjal. Pada trimester pertama ini pemeriksaan USG digunakan untuk mengkonfirmasi kehamilan dan menghitung hari perkiraan lahir (HPL).

Pemeriksaan kehamilan di trimester kedua meliputi cek darah, untuk mengetahui adanya kelainan di tabung saraf tulang belakang, kemungkinan akan terjadinya down syndrome, diabetes gestasional, dan menghitung kadar gula darah dalam tubuh. Sedangkan pada tes urine dilakukan pemeriksaan untuk mengetahui kemungkinan adanya infeksi saluran kemih dan preeklampsia. Pemeriksaan USG juga dilakukan untuk mengetahui usia kehamilan, menghitung panjang mulut rahim, dan gerakan janin.

Pemeriksaan trimester ketiga dilakukan pemeriksaan USG untuk memantau jumlah cairan ketuban, tumbuh kembang janin dengan mengukur tulang paha, ukuran kepala dan perut si kecil. USG juga dilakukan untuk mengecek 
posisi bayi apakah sungsang atau tidak. Apabila ibu lewat HPL, maka USG dilakukan untuk memeriksa detak jantung bayi dan kondisi kesehatan bayi, lokasi plasenta dan kondisi serviks terkait kesiapannya untuk persalinan. Semua jenis pemeriksaan tersebut dilakukan untuk memastikan kondisi ibu dan bayi selama masa kehamilan. Variasi jenis tes bisa berbeda antara ibu hamil yang satu dengan lainnya, terutama jika ada komplikasi kehamilan. Komplikasi kehamilan dapat dicegah salah satunya dengan menjaga jarak kehamilan antara anak yang satu dengan anak yang lainnya melalui kontrasepsi pasca persalinan.

Kontrasepsi merupakan upaya untuk mencegah kehamilan baik secara permanen ataupun sementara (Sarwono, 2006). Tujuan kontrasepsi yaitu mencegah terjadinya fertilisasi dengan mencegah implantasi sel telur yang telah dibuahi (Brooker,2008). Adapun alat kontrasepsi tersebut di antaranya suntikan, kontrasepsi oral, kondom, kontrasepsi intravaginal, Inttrauterine device (IUD) atau AKDR, operasi (Fasektomi atau tubektomi), konvensional (Staf pengajar, FKUS, 2009). Memilih alat kontrasepsi bukan merupakan hal yang mudah karena efek yang berdampak terhadap tubuh tidak akan diketahui selama belum menggunakannya (Kamaludin, 2012). Pelayanan kontrasepsi tersebut mempunyai tujuan untuk menurunkan angka kelahiran yang bermakna yaitu dengan menjaga jarak kelahiran yang terlalu dekat (Hartono, 2004). Hal ini telah diatur pada Undang-undang RI No. 52 tahun 2009, yaitu upaya untuk mengatur kelahiran anak, jarak dan usia ideal melahirkan, mengatur kehamilan melalui program promosi kesehatan, dan perlindungan serta bantuan sesuai hak reproduksi untuk mewujudkan keluarga yang berkualitas (Mendagri, 2009).

Upaya yang dapat dilakukan tenaga kesehatan untuk menyukseskan program pemerintah tersebut, yaitu dengan memberikann intervensi kepada ibu hamil dan keluarga terkait penggunaan alat kontrasepsi pasca persalinan melalui pendidikan kesehatan. Pemberian pendidikan kesehatan pada periode postpartum dapat meningkatkan pengetahuan ibu serta mempengaruhi penggunaan alat kontrasepsi dalam 12 minggu pertama setelah melahirkan.

Hasil studi pendahuluan yang dilakukan di Puskesmas Kedung 2 Jepara didapatkan bahwa 7 ibu hamil trimester ketiga yang diwawancarai didapatkan data bahwa 3 ibu menyatakan saat ini merupakan kehamilan pertama dan belum pernah menggunakan alat kontrasepsi, 1 ibu berada pada kehamilan yang kedua dan pernah menggunakan alat kontrasepsi suntikan, dan 3 ibu berada kehamilan lebih dari 3 kali dimana 1 ibu pernah menggunakan alat kontrasepsi suntik dan 2 ibu tidak menggunakan alat kontrasepsi. Berdasarkan latar belakang tersebut, diketahui bahwa tingkat pengetahuan ibu dalam penggunaan kontrasepsi pasca persalinan yang beragam mencerminkan perilaku ibu mengambil keputusan dalam menentukan alat kontrasepsi, hal ini juga tidak terlepas dari peran dan kesepakatan dengan suami sehingga perlu dilakukan penelitian yang bertujuan untuk mengetahui hubungan karakteristik ibu hamil dengan pengetahuan dalam penggunaan kontrasepsi pasca persalinan.

\section{METODE PENELITIAN \\ Jenis Penelitian}

Penelitian ini merupakan penelitian kuantitatif dengan pendekatan deskriptif eksploratif. Penelitian dilakukan pada ibu hamil yang melakukan pemeriksaan kehamilan di Puskesmas Kedung 2 Jepara Jawa Tengah dalam kurun tertentu.

\section{Lokasi dan Waktu Penelitian}

Penelitian ini dilaksanakan di Puskesmas Kedung 2 Jepara Jawa tengah pada Bulan Desember 2019 - Januari 2020.

\section{Populasi dan Sampel}

Populasi penelitian adalah semua ibu hamil yang melakukan pemeriksaan kehamilan Teknik sampling menggunakan total sampling. Penelitian ini telah dilakukan pada 34 ibu hamil yang melakukan pemeriksaan kehamilan di Puskesmas Kedung 2 Jepara.

\section{Pengumpulan Data}

Alat pengumpul data menggunakan kuesioner yang terdiri dari usia, pendidikan, pekerjaan, penghasilan, jumlah anak, dan status kehamilan. Tingkat pengetahuan responden diukur menggunakan kuesioner yang terdiri dari 40 pernyataan yang selanjutnya dikategorikan menjadi 3 tingkatan yaitu kurang $(<56 \%)$, cukup $(56-75 \%)$, baik $(76-100 \%)$.

\section{Pengolahan dan Analisis Data}


Data dianalisis secara univariat menggunakan distribusi frekuensi dan analisis bivariat menggunakan uji chi square.

\section{HASIL PENELITIAN}

Tabel 1 menunjukkan bahwa rerata usia ibu hamil 29 tahun, rerata usia suami ibu hamil 33 tahun, dan rerata penghasilan ibu hamil $\mathrm{Rp}$. $1.500 .000 /$ bulan.

Tabel 1. Distribusi Usia, Usia Suami, dan Penghasilan Responden (n=34)

\begin{tabular}{lc}
\hline \multicolumn{1}{c}{ Mean (tahun) } & Min-Max \\
\hline Usia Responden & \\
$\quad 28,85$ & $18-40$ \\
Usia Suami Responden & \\
$\quad 33,26$ & $23-43$ \\
Penghasilan Responden & \\
$\quad 1.519 .117$ & $400.000-3.000 .000$ \\
\hline
\end{tabular}

Tabel 2 menunjukkan bahwa mayoritas ibu hamil berpendidikan SLTA, mayoritas suami ibu hamil berpendidikan SLTA, mayoritas ibu hamil bekerja, dan mayoritas ibu hamil telah memiliki anak berjumlah 1 .

Tabel 2. Distribusi Pendidikan, Pendidikan Suami, Pekerjaan Ibu, dan Jumlah Anak (n=34)

\begin{tabular}{lcc}
\hline \multicolumn{1}{c}{ Variabel Penelitian } & n & \% \\
\hline Pendidikan & 5 & \\
$\quad$ SD & 14 & 14,7 \\
SLTP & 13 & 41,2 \\
SLTA & 2 & 38,2 \\
Perguruan Tinggi & & 5,9 \\
Pendidikan Suami & 11 & 32,4 \\
$\quad$ SD & 8 & 33,5 \\
SLTP & 13 & 38,2 \\
SLTA & 2 & 5,9 \\
Perguruan Tinggi & & \\
Pekerjaan Ibu & 33 & 97,1 \\
Bekerja & 1 & 2,9 \\
Tidak bekerja & & \\
Jumlah Anak & 10 & 29,4 \\
0 & 13 & 38,3 \\
1 & 5 & 14,7 \\
2 & 6 & 17,6 \\
3
\end{tabular}

Hasil penelitian terkait tingkat pengetahuan ibu hamil tentang penggunaan kontrasepsi suntik pasca persalinan menunjukkan mayoritas ibu hamil memiliki tingkat pengetahuan baik.

Hasil analisis bivariat menunjukkan bahwa usia, pendidikan, pekerjaan, dan jumlah anak mempunyai hubungan yang bermakna dengan pengetahuan ibu hamil dalam penggunaan kontrasepsi pasca persalinan. Sedangkan karakteristik penghasilan tidak memiliki hubungan yang bermakna dengan pengetahuan ibu hamil dalam penggunaan kontrasepsi pasca persalinan. 
Tabel 3. Tingkat Pengetahuan Ibu Hamil tentang Penggunaan Kontrasepsi Suntik Pasca Persalinan $(\mathbf{n}=34)$

\begin{tabular}{lcc}
\hline \multicolumn{1}{c}{ Tingkat Pengetahuan } & n & \% \\
\hline Kurang $(<56 \%)$ & 0 & 0 \\
Cukup $(56-75 \%)$ & 6 & 17,6 \\
Baik $(76-100 \%)$ & 28 & 82,4 \\
\hline
\end{tabular}

Tabel 4. Hubungan Karakteristik Ibu Hamil dengan Pengetahuan dalam Penggunaan Kontrasepsi Pasca Persalinan

\begin{tabular}{lccc}
\hline \multicolumn{1}{c}{ Variabel } & Hasil Uji Chi Square & Hasi Uji Regresi Linear & Omnibus test \\
\hline Usia & 0.027 & .034 & \\
Pendidikan & 0.002 & .007 & 0.002 \\
Pekerjaan & 0.004 & .023 & \\
Penghasilan & 0.923 & .884 & \\
Jumlah Anak & 0.006 & .048 & \\
\hline
\end{tabular}

\section{PEMBAHASAN}

\section{Usia Ibu Hamil}

Hasil penelitian menunjukkan rata-rata ibu hamil berusia 29 tahun. Usia tersebut dikategorikan dalam usia dewasa awal. Menurut Depkes (2013) Usia dewasa awal adalah individu yang berada pada usia $22-30$ tahun. Hasil analisis menunjukkan bahwa ibu yang berusia 29 tahun mayoritas memiliki tingkat pengetahuan baik. Hasil analisis bivariat juga menunjukkan bahwa usia mempunyai hubungan yang bermakna dengan pengetahuan ibu dalam penggunaan kontrasepsi pasca persalinan dengan nilai $\mathrm{p}=0.027$. Hal ini dikarenakan usia ibu yang produktif sehingga ibu cenderung mencari informasi dalam penggunaan kontrasepsi melalui media online yang sangat mudah diakses ibu, selain itu ibu juga aktif mengunjungi pelayanan kesehatan.

Hasil penelitian ini sejalan dengan penelitian Bernadus, Madianung, dan Masi (2013) yang dilakukan di Puskesmas Mabapura Kabupaten Halmahera Timur bahwa mayoritas ibu yang diukur tingkat pengetahuan terkait penggunaan alat kontrasepsi adalah ibu yang berusia dewasa awal. Hasil penelitian Handayani (2012) yang dilakukan di Desa Rambigundam Kabupaten Jember juga didapatkan hasil bahwa mayoritas ibu yang mendapatkan dukungan keberfungsian kekuatan keluarga dalam pemilihan alat kontrasepsi adalah ibu berusia dewasa awal. Hasil penelitian ini berbeda dengan penelitian Khairunnisa, Purwanti, \& Wijayanti (2018) bahwa mayoritas ibu yang menjadi responden pada penelitian terkait faktor yang berhubungan dengan penggunaan alat kontrasepsi adalah ibu yang berusia 31 tahun yang tergolong dalam usia dewasa akhir. Hasil penelitian ini juga berbeda dengan penelitian Muryani, Dewi, Rachmasari (2016) bahwa mayoritas ibu berusia dewasa akhir yang menjadi responden dalam penelitian terkait hubungan partisipasi suami dalam penggunaan alat kontrasepsi dengan penggunaan metode kontrasepsi jangka panjang pada ibu.

Hasil penelitian yang peneliti lakukan menunjukkan bahwa rata-rata suami responden berusia 33 tahun yang termasuk dalam kategori dewasa awal. Hasil ini sejalan dengan penelitian Fitria dan Nuryanti (2014) bahwa mayoritas usia suami yang berpartisipasi dalam ber-KB dalam kategori dewasa awal. Hasil penelitian ini sesuai dengan pendapat Erikson (1989) usia dewasa awal yaitu 20 - 40 tahun merupakan tahap perkembangan psikososial antara keintiman atau keakraban vs keterasingan atau kesendirian.

Hasil ini juga sejalan dengan penelitian Priyambodo dan Setyawan (2019) bahwa pada tahap dewasa awal individu mempunyai beberapa masalah dalam perkembangan di antaranya Penentuan identitas diri ideal vs kekaburan identitas, kemandirian vs tidak mandiri, sukses meniti jenjang pendidikan dan karir vs gagal menempuh jenjang pendidikan dan karir, menikah vs tidak menikah (lambat menikah), hubungan sosial yang sehat vs menarik diri. Berdasarkan hasil penelitian, teori dan penelitian sebelumnya dapat disimpulkan 
bahwa individu dengan usia dewasa awal secara sosial menjalin hubungan kasih dengan suami atau istri sehingga tercipta rasa cinta dan kebersamaan. Hal ini dapat disimpulkan bahwa apabila tugas perkembangan psikososial usia dewasa awal tidak terpenuhi, maka individu akan merasa kesepian dan tidak berharga.

\section{Pendidikan Ibu}

Hasil penelitian menunjukkan bahwa ibu yang menjadi responden dalam penelitian terkait pengetahuan ibu dalam penggunaan kontrasepsi suntik pasca persalinan mayoritas berpendidikan terakhir SLTA. Hasil analisis bivariate menunjukkan bahwa pendidikan mempunyai hubungan bermakna dengan pengetahuan ibu dalam penggunaan kontrasepsi pasca persalinan dengan nilai $\mathrm{p}=0,002$. Hal ini terjadi karena pendidikan ibu yang mayoritas SLTA sehingga ibu mampu menggunakan mencari informasi secara mandiri dengan menggunakan media online, sehingga informasi yang didapat mampu meningkatkan pengetahuan ibu, selain itu ibu hamil juga rajin mengunjungi pelayanan kesehatan yang berada di sekitar tempat tinggalnya.

Hasil ini sejalan dengan penelitian Putriningrum (2010) bahwa penelitian terkait faktor-faktor yang mempengaruhi ibu dalam pemilihan kontrasepsi mayoritas berpendidikan SLTA. Hasil ini berbeda dengan penelitian Bernadus, Madianung, dan Masi (2013) bahwa mayoritas ibu yang menjadi responden dalam penelitian terkait hubungan pengetahuan tentang $\mathrm{KB}$ dengan penggunaan alat kontrasepsi adalah mayoritas ibu berpendidikan terakhir SLTP. Hasil ini juga berbeda dengan penelitian Hasil penelitian ini juga berbeda dengan penelitian Muryani, Dewi, Rachmasari (2016); Ahmad, Hutagaol, Malara (2014) bahwa mayoritas ibu berpendidikan terakhir SLTP.

Berdasarkan hasil penelitian menunjukkan bahwa suami responden juga mayoritas berpendidikan SLTP. Hasil ini sejalan dengan penelitian Fitria dan Yanti (2014) bahwa mayoritas suami yang berpartisipasi dalam ber-KB berpendidikan terakhir SD, dan menyatakan bahwa pendidikan mempengaruhi hubungan antara pengetahuan suami tentang $\mathrm{KB}$ dengan partisipasi suami dalam ber-KB. Hasil ini berbeda dengan penelitian Suantari (2019) bahwa mayoritas pendidikan terakhir suami adalah SLTA, dimana responden lebih cepat menangkap informasi yang disampaikan dibandingkan dengan responden yang berpendidikan dasar.

Hasil penelitian ini sejalan dengan penelitian Prasetyaningtyas (2011) bahwa tingkat pendidikan mempunyai pengaruh terhadap minat mengikuti program KB. Semakin tinggi tingkat pendidikan maka semakin tinggi juga minat untuk berpartisipasi dalam KB. Penelitian Putri (2016) juga menunjukkan hal yang sama bahwa pendidikan berhubungan dengan perilaku KB.

Berdasarkan beberapa hasil penelitian tersebut peneliti berpendapat bahwa pengetahuan sangat erat hubungannya dengan pendidikan, dimana individu dengan pendidikan yang tinggi diharapkan mempunyai pengetahuan yang semakin luas pula. Namun perlu ditekankan bahwa bukan berarti individu yang memiliki pendidikan rendah mutlak rendah pula pengetahuannya. Hal ini mengingat bahwa peningkatan pengetahuan tidak hanya didapatkan dari pendidikan formal, namun dapat berasal dari pendidikan non formal.

Hal ini sesuai Notoatmodjo (2010) bahwa pendidikan merupakan salah satu faktor yang dapat mempengaruhi sikap terhadap kontrasepsi, dimana individu yang berpendidikan tinggi akan memberikan respon yang lebih rasional dari mereka yang berpendidikan rendah. Individu yang berpendidikan tinggi lebih kreatif dan lebih dapat menyesuaikan diri terhadap perubahan sosial. Berdasarkan hasil penelitian dan penelitian sebelumnya dapat peneliti simpulkan bahwa tingkat pendidikan ibu hamil dan suami dapat mempengaruhi pengetahuan dalam penggunaan kontrasepsi suntik pasca persalinan, dimana pendidikan dapat mempengaruhi individu untuk bersikap sehingga semakin tinggi pendidikan individu maka semakin mudah individu untuk menerima dan mencari informasi. Hal ini sesuai dengan rekomendasi Curtis, Jatlaoui, Tepper, Zapata, Horton, Jamieson, dan Whiteman (2016) bahwa individu harus mencari informasi dari penyedia layanan kesehatan mereka ketika mempertimbangkan pilihan dalam penggunaan kontrasepsi.

\section{Pekerjaan Ibu}

Hasil penelitian menunjukkan bahwa mayoritas ibu yang menjadi responden dalam penelitian terkait tingkat pengetahuan ibu dalam penggunaan kontrasepsi pasca persalinan 
memiliki status bekerja. Hasil analisis bivariate menunjukkan bahwa pekerjaan memiliki hubungan yang bermakna dengan pengetahuan ibu dalam penggunaan kontrasepsi pasca persalinan dengan nilai $\mathrm{p}=0,004$. Ibu yang bekerja mempunyai wawasan yang lebih luas sehingga informasi yang didapatkan terkait penggunaan kontrasepsi juga akan didapat dari teman kerja. Hasil ini sejalan dengan penelitian Fitria dan Nuryanti (2014); bahwa mayoritas ibu hamil dengan usia dewasa muda berstatus bekerja. Hasil ini berbeda dengan penelitian Muryani dan Rachmasari (2016) bahwa mayoritas ibu tidak bekerja yaitu sebagai ibu rumah tangga. Hasil ini mendukung pernyataan Priyambodo dan Setyawan (2019) bahwa individu pada tahap dewasa awal mempunyai beberapa masalah salah satunya kemandirian vs tidak mandiri. Menurut Livana, Keliat, Putri (2015) bahwa bekerja merupakan salah satu tugas perkembangan psikososial yang normal pada usia dewasa.

Hasil ini juga sependapat dengan penelitian Mubin, Livana, dan Rinawati (2019) bahwa Individu Yang berada pada usia dewasa, cenderung memikirkan masalah keluarga dan ekonomi sehingga individu tersebut berusaha untuk bekerja. Berdasarkan hasil penelitian dan penelitian sebelumnya, peneliti dapat simpulkan bahwa ibu hamil dengan usia dewasa awal mempunyai status bekerja, merupakan salah satu bukti bahwa ibu hamil juga memikirkan masalah ekonomi keluarga dan telah menjalankan tugasnya sebagai individu yang berusia dewasa agar tetap berada pada tahap perkembangan psikososial yang normal.

\section{Penghasilan}

Hasil penelitian menunjukkan bahwa mayoritas responden memiliki penghasilan ratarata Rp. 1.500.000,-/bulan. Hasil penelitian ini dikaitkan dengan pengetahuan responden dalam penggunaan kontrasepsi pasca persalinan, dimana hasil analisis menunjukkan bahwa penghasilan tidak memiliki hubungan yang bermakna dengan pengetahuan ibu dalam penggunaan kontrasepsi pasca persalinan (nilai $\mathrm{p}=0,923$ ) beberapa penelitian menunjukkan bahwa responden dengan status ekonomi tidak mampu memiliki minat yang sama dengan responden dengan status ekonomi mampu, hal ini dipengaruhi dengan rendahnya biaya KB di Indonesia (Khairunnisa, Purwanti, \& Wijayanti, 2018). Hasil penelitian ini sejalan dengan penelitian Prasetyo (2013) bahwa status ekonomi tidak berhubungan dengan minat mengikuti Program KB.

Hasil penelitian Suseno (2011) mempunyai pendapat yang berbeda bahwa status ekonomi berpengaruh terhadap minat mengikuti Program KB. Status ekonomi dapat membuat perbedaan orientasi tentang nilai anak antara masyarakat maju (status ekonomi mampu) dan masyarakat tertinggal (status ekonomi tidak mampu). Masyarakat miskin misalnya, nilai anak lebih bersifat barang produksi. Artinya anak yang dilahirkan lebih ditekankan pada aspek jumlah atau banyaknya anak yang dimiliki (kuantitas). Berdasarkan hasil penelitian dan penelitian sebelumnya, peneliti dapat simpulkan bahwa penghasilan atau status ekonomi ibu hamil tidak berpengaruh dengan minat mengikuti program $\mathrm{KB}$, namun berpengaruh terhadap orientasi nilai anak antara masyarakat maju (status ekonomi mampu) dan masyarakat tertinggal (status ekonomi tidak mampu).

\section{Jumlah anak}

Hasil penelitian menunjukkan bahwa mayoritas responden telah memiliki 1 orang anak. Hasil uji bivariat menunjukkan bahwa jumlah anak memiliki hubungan yang bermakna dengan pengetahuan ibu dalam penggunaan kontrasepsi pasca melahirkan dengan nilai $\mathrm{p}=0,006)$. Hasil ini memberikan gambaran bahwa ibu hamil sebelumnya pernah hamil dan telah melahirkan anak sebelumnya, sehingga secara psikologis tingkat ansietas yang dihadapi ibu hamil juga berbeda dibandingkan saat pertama hamil. Hasil ini sesuai dengan penelitian Livana, Fatoni, Mubin (2019) bahwa pengalaman sebelumnya akan mempengaruhi tingkat ansietas individu. Jika dikaitkan dengan penelitian sebelumnya, ibu hamil yang telah memiliki anak sebelumnya telah memiliki pengalaman dalam program KB termasuk pengetahuan terkait penggunaan kontrasepsi pasca melahirkan.

Hal ini sesuai dengan penelitian White, Teal, dan Potter (2015).yang bertujuan untuk mengetahui pola penggunaan kontrasepsi wanita setelah melahirkan dan hubungan antara penggunaan metode dan risiko kehamilan dalam waktu 18 bulan pada 3.005 kelahiran yang terjadi dalam waktu 3 tahun diketahui bahwa mayoritas wanita menggunakan kontrasepsi reversibel jangka panjang pasca 
melahirkan, sedangkan responden yang menggunakan metode kurang efektif memiliki peningkatan risiko kehamilan yang tidak diinginkan.

\section{Status kehamilan}

Hasil penelitian menunjukkan bahwa mayoritas responden berada pada kehamilan ke 1 dan ke 2, hasil ini sejalan dengan penelitian Handayani (2012) bahwa ada hubungan keberfungsian kekuatan keluarga dengan pemilihan metode kontrasepsi, dimana jumlah anak dalam keluarga paling banyak memiliki 2 anak. Hasil ini sejalan dengan penelitian Roe, McAllister, Sammel, Schreiber (2020) bahwa dari 244 responden (50\%) menyatakan kehamilan ini telah direncanakan, dan 218 (90\%) menyatakan bahwa mereka telah merencanakan untuk melanjutkan kehamilan hingga cukup bulan, 97 peserta (40\%) merencanakan kontrasepsi, 33 (14\%) memilih metode reversible jangka panjang, 44 (18\%) metode reversibel aksi pendek, dan 20 (8\%) kontrasepsi kondom atau darurat, sedangkan 147 (60\%) menolak kontrasepsi.

Hasil penelitian ini berbeda dengan penelitian Flink-Bochacki, Hamm, Borrero, Chen, Achilles, Chang (2018) yang dilakukan pada 26 wanita yang mengalami aborsi spontan. Hasil penelitian tersebut menunjukkan bahwa seluruh responden menerima gagasan konseling kontrasepsi dimana $54 \%$ berusaha untuk hamil, $27 \%$ tidak berusaha tetapi tidak mencegah, dan $19 \%$ berusaha menghindari kehamilan.

\section{KESIMPULAN DAN SARAN}

Hasil penelitian dapat disimpulkan bahwa rata-rata usia ibu hamil 29 tahun. Mayoritas ibu hamil berpendidikan terakhir SLTA, bekerja, dan berpenghasilan rata-rata Rp. 1.500.000,-/bulan. Mayoritas ibu hamil telah memiliki anak berjumlah 1 dan saat pengambilan data ibu hamil berstatus hamil ke 1 dan ke 2. Mayoritas tingkat pengetahuan ibu hamil tentang penggunaan kontrasepsi suntik pasca persalinan berada pada tingkat pengetahuan baik.

Hasil analisis uji chi square menunjukkan karakteristik ibu hamil yang mempunyai hubungan bermakna dengan pengetahuan dalam penggunaan kontrasepsi pasca persalinan yaitu usia, pendidikan, pekerjaan, jumlah anak. Sedangkan penghasilan tidak memiliki hubungan yang bermakna dengan pengetahuan ibu dalam penggunaan kontrasepsi pasca persalinan. Peneliti selanjutnya diharapkan dapat melanjutkan penelitian ini berupa penelitian dengan memberikan perlakuan kepada ibu hamil guna menganalisis tingkat pengetahuan ibu hamil sebelum dan sesudah diberikan perlakuan.

\section{DAFTAR PUSTAKA}

Ahmad, S., Hutagaol, E., \& Malara, R. (2014). Hubungan Pengetahuan Ibu Usia Remaja dan Dewasa Muda Tentang KB dengan Penggunaan Alat Kontrasepsi Setelah Melahirkan di Puskesmas Mabapura Kabupaten Halmahera Timur. Jurnal Keperawatan, 2(2). https://ejournal. unsrat.ac.id/index.php/jkp/article/view/60 33.

Andrea H. Roe, Arden McAllister, Mary D. Sammel, Courtney A. Schreiber. (2020). Pregnancy intentions and contraceptive uptake after miscarriage. Contraception. https://doi.org/10.1016/j.contraception.20 20.03.002.

Bernadus, J. D., Madianung, A., \& Masi, G. (2013). Faktor-faktor yang berhubungan dengan pemilihan alat kontrasepsi dalam rahim (AKDR) bagi akseptor $\mathrm{KB}$ di Puskesmas Jailolo. e-NERS, 1(1). https:// ejournal.unsrat.ac.id/index.php/jkp/article /view/6033/5552.

Buletin Kespro. 2013. Situasi Keluarga Berencana di Indonesia. Jakarta: Kementrian Kesehatan RI.

Curtis, K. M., Jatlaoui, T. C., Tepper, N. K., Zapata, L. B., Horton, L. G., Jamieson, D. J., \& Whiteman, M. K. (2016). US selected practice recommendations for contraceptive use, 2016. Morbidity and Mortality Weekly Report: Recommendations and Reports, 65(4), 166.

Depkes, 2013. Rencana Aksi Nasional Pelayanan Keluarga Berencana 20142015. (online), (http:www.gizikia. depkes.go.id/wp-content/uploads/ 2014/ 01/RAN-PELAYANAN-KB.pdf, diakses tanggal 05 April 2020.

Dinas Kesehatan Provinsi Bali. (2015) Profil Kesehatan Provinsi Bali Tahun 2014 Denpasar: Dinas Kesehatan Provinsi Bali.

Erik H. Erikson. (1989). Identitas dan Siklus Hidup Manusia, Jakarta: Penerbit 
Gramedia, 1989 Losoncy, Lawrence J. Religious Education and the Life-cycle. Catecethical Communication. Monk, F.J., AMP Knoers \& S.R. Hadinoto. Psikologi Perkembangan, Gadjah Mada University Press.

Fitria, D., \& Nuryanti, S. (2014). Hubungan Antara Pengetahuan Suami Tentang KB Dengan Partisipasi Suami Dalam Ber-Kb Di Kelurahan Kemang Kabupaten Bogor. Jurnal Ilmiah Kesehatan Diagnosis, 5(5), 627-631. http://www. ejournal.stikesnh.ac.id/index.php/jikd/arti cle/view/216.

Flink-Bochacki, R., Hamm, M. E., Borrero, S., Chen, B. A., Achilles, S. L., \& Chang, J. C. (2018). Family planning and counseling desires of women who have experienced miscarriage. Obstetrics and gynecology, 131(4), 625.

Handayani, Tutut. (2012). Hubungan keberfungsian kekuatan keluarga dengan pemilihan metode kontrasepsi di desa rambigundam kecamatan rambipuji kabupaten jamber. http://repository.unej.ac.id/bitstream/han dle/123456789/3243/Tutut\%20Handayan i.pdf? sequence $=1$.

Kamaludin, A. (2012). Sistem pendukung keputusan dalam pemilihan alternatif alat kontrasepsi menggunakan simple additive weighting (Doctoral dissertation, UIN Sunan Gunung Djati Bandung).

Khairunnisa, I., Purwanti, S. K. M., \& Wijayanti, A. C. (2018). Faktor-faktor yang Berhubungan dengan Minat Pasangan Usia Subur dalam Mengikuti Program KB di Desa Jaraksari, Kabupaten Wonosobo (Doctoral dissertation, Universitas muhammadiyah Surakarta). http://eprints. ums.ac. id/60723/13/NASKAH\%20PUBLIKASI $\% 2012$.pdf.

Livana, P. H., Fatoni, N., \& Mubin, M. F. (2019). Gambaran Tingkat Ansietas Suami Atau Istri Yang Ditinggal Pasangannya Bekerja Diluar Negeri. Jurnal Keperawatan Jiwa, 5(1), 48-52. https:// jurnal.unimus.ac. id/index. php/JKJ/article/view/4486/4090.

Livana, P. H., Keliat, B. A., \& Putri, Y. S. E. (2016). Penurunan Tingkat Ansietas Klien Penyakit Fisik Dengan Terapi Generalis Ansietas Di Rumah Sakit
Umum Bogor. Jurnal Keperawatan, 8(2), 64-73. http://journal. stikeskendal.ac.id/ index.php/Keperawatan/article/view/40.

Mubin, M. F., Livana, P. H., \& Rinawati, F. (2019). Usia dan Jenis Kelamin Berhubungan dengan Tingkat Ansietas Pasangan yang Ditinggal Bekerja Keluar Negeri. Coping: Community of Publishing in Nursing,7(3), 165-170. https://ojs.unud.ac.id/index.php/coping/ar ticle/view/55801.

Muryani, S., Dewi, R. C., \& Rachmasari, A. (2016). Hubungan Partisipasi Suami Dalam Penggunaan Alat Kontrasepsi Dengan Penggunaan Metode Kontrasepsi Jangka Panjang (MKJP) Pada Ibu Di Desa Kalisapu Kabupaten Tegal. Bhamada: Jurnal Ilmu dan Teknologi Kesehatan (E-Journal), 7(1), 8-8. http://ojs. stikesbhamadaslawi.ac. id/index.php/jik/article/view/41.

Notoatmodjo, S. (2010). Promosi Kesehatan dan Ilmu Perilaku. Jakarta; Rineka Cipta.

Prasetyaningtyas, P. (2011). Peningkatan Minat dan Keputusan Berpartisipasi Akseptor KB. Jurnal Dinamika Kesehatan, Vol 2 No. 2.

Prasetyo, T. (2013). Analisis Faktor yang Mempengaruhi PUS Mengikuti Keluarga Berencana di Wilayah Kerja Puskesmas Sambirejo Kabupaten Sragen. Surakarta: Universitas Muhammadiyah Surakarta.

Priyambodo, A. B., \& Setyawan, H. (2019). Problematika Sosial Mahasiswa di Universitas Negeri Malang Ditinjau Dari Perspektif Perkembangan Psikososial. Prosiding Seminar Nasional \& Call Paper Psikologi Sosial 2019. Fakultas pendidikan Psikologi, Aula C1, 4 Mei 2019. http://fppsi.um. ac.id/ wp-content/ uploads/2019/07/Aji-Bagus.pdf.

Putri, Dwi, P (2016). Pengaruh Tingkat Pendidikan, Pengetahuan, Sikap, dan Terpaan Iklan Layanan Masyarakat KB Versi Shireen Sungkar dan Teuku Wisnu di TV Terhadap Perilaku KB Wanita atau Pria Usia Subur. Jurnal Interaksi.

Putriningrum, Rahajeng. 2010. Faktor-faktor yang mempengaruhi ibu dalam pemilihan kontrasepsi KB suntik di BPS. Ruvina Surakarta. (online). http://jurnal. stikeskusumahusada.ac.id/i ndex.php/JK/ article/view/63/66. Diakses tanggal 16 september, jam 14.34). 
Sari, E. P. (2018). Faktor-Faktor Yang Mempengaruhi Akseptor $\mathrm{Kb}$ Dalam Penggunaan Alat Kontrasepsi Dalam Rahim Di Puskesmas Sidomulyo. Jurnal Kesehatan Husada Gemilang, 1(2), 1-9. http://jurnal.husadagemilang.ac.id/index. php/jkhuge/article/view/11.

Suantari, N. W. A. (2019). Efektivits Pemberian Pendidikan Kesehatan terhadap Peningkatan Pengetahuan Suami Mengenai Kontrasepsi Vasektomi Di Dusun Giling Kecamatan Pabelan Kabupaten Semarang (Doctoral dissertation, Universitas Ngudi Waluyo). http://repository2.unw.ac.id/282/1/artikel. pdf.

Suseno, R,.M. (2011). Faktor-faktor Yang Berpengaruh Terhadap Kebutuhan Keluarga Berencana yang Tidak Terpenuhi (Unmet Need for Family Planning) di Kota Kediri. Jurnal Kebidanan Panti Wilasa, Vol. 2 No. 1. Oktober.

White, K., Teal, S. B., \& Potter, J. E. (2015). Contraception after delivery and short interpregnancy intervals among women in the United States. Obstetrics and gynecology, 125(6), 1471. 